\title{
Vliv vybraných proměnných na environmentální gramotnost žáků 2. stupně základní školy
}

\section{Silvie Svobodová}

Envigogika 12 (1) - Recenzované články/ Reviewed Papers

Publikováno/Published dne 24. 5. 2017

DOI : $\underline{10.14712 / 18023061.539}$

\begin{abstract}
Abstrakt
Článek se věnuje zjištóvání vlivu determinantů z oblasti sociodemografických proměnných na kognitivní a afektivní aspekt environmentální gramotnosti žáků druhého stupně Základní školy Žatec, nám. 28. řína 1019, okres Louny. Autorka testuje výzkumný nástroj složený z testu MSELS a dvoudimenzionální škály 2-MEV na vzorku tvořeném 87 respondenty z 6. až 9 . ročníků. Studie předkládá výsledky týkající se vlivu pohlaví, bydliště, věku respondentů a realizovaných volnočasových aktivit na naměřené hodnoty environmentálních vědomostí a proenvironmentálních postojů. Vztah mezi vědomostmi a postoji byl identifikován jako nepř́liš těsný na rozdíl od středně silné pozitivní korelace mezi oběma faktory škály 2MEV. $V$ prípadě pohlaví a velikosti bydliště nebyl prokázán signifikantní vliv těchto proměnných ani u jednoho ze zkoumaných aspektů. Stejné závěry byly potvrzeny u věku respondentů a volnočasových aktivit ve vztahu $\mathrm{k}$ vědomostem, ovšem u postojů byl zaznamenán významný vliv obou determinantů. Nejpříznivěji ve smyslu pozitivního vlivu na afektivní složku se $z$ volnočasových aktivit projevily aktivity zaměřené na pobyt $v$ prírodě a sport. Ačkoli tyto výsledky nejsou reprezentativní, závěr nabízí nové výzkumné otázky pro další, rozsáhlejší šetření.
\end{abstract}

\section{Klíčová slova} MEV

Environmentální gramotnost, demografické proměnné, environmentální vědomosti, 2-

\begin{abstract}
The contribution is devoted to investigating the impact of sociodemographic variables of the area on the cognitive and affective aspect of environmental literacy among 12-15 years old students in Žatec, Square 28 October 1019, district of Louny. The author tested two research instruments: MSELS and two-dimensional scales of 2-MEV on the research sample consisting from 87 respondents from 6 to 9 th grades of these school. The study presents the results regarding the influence of gender, domicile, age of the respondents and their leisure time activities on the measured figures of environmental knowledge and proenvironmental attitudes. The relation between the knowledge and the attitudes was identified not too tight in contrast to medium-strong positive correlation between the two factors of 2MEV scales. In the case of sex and place of residence (village/city) no significant effect was proved, either in one of the aspects. The identical conclusions were confirmed concerning
\end{abstract}


the age of respondents, and leisure time activities in relation to their knowledge. However, talking about attitudes there was a significant effect of both determinants. Leisure time outdoor and sports activities in the nature manifested the most positive influence on the affective component. Even if these results are not representative, the new research questions for wider survey are offered in the conclusions.

\section{Key words}

Environmental literacy, demographic variables, environmental knowledge, 2-MEV

\section{Teoretická východiska}

Vychovat $z$ dítěte jedince zodpovědného a šetrného $\mathrm{k}$ životnímu prostředí má za cíl (obdobně jako mnohé jiné výchovně vzdělávací oblasti) environmentální výchova. Je založena především na zprostředkování uceleného souboru znalostí a dovedností a spočívá v průběžném upevňování a rozvíjení schopnosti přemýšlet ve vzájemných souvislostech. Jejím úkolem je také motivace $k$ aktivní a efektivní ochraně životního prostředí včetně vytváření pozitivního vztahu k prírodě (Činčera, 2007).

Komplexně pojmout stěžejní cíl environmentální výchovy se snaží koncept, který nazýváme environmentální gramotnost ${ }^{1}$ (Roth, 1992; Volk et al., 1984; Hungerford et al., 1994; Daniš, 2013). Současná, výzkumy podložená (Hollweg et al., 2011), koncepce environmentální gramotnosti se skládá ze tři dimenzí - kognitivní, afektivní a konativní. Výzkumníci se nejčastěji zaměřují na jejich kombinaci (Kroufek, 2016), přičemž nejvíce pozornosti věnují zvláště dimenzi afektivní (Hollweg et al., 2011). Výzkum této oblasti je mnohdy realizován pomocí výzkumných nástrojů založených na kvantitativních metodách, nejčastěji formou dotazníkového šetření či testu. Kvantitativní přístup popisuje a vysvětluje konkrétní jevy prostřednictvím numerických dat a statistických metod. Děje se tak při použití výzkumného nástroje na velkém, úzce definovaném, obvykle reprezentativním výzkumném vzorku, pomocí kterého Ize analyzovat například výstupy vzdělávacího procesu, nikoliv jeho probíhající procesy. Protože zkoumané jevy jsou výsledkem dotazování, otázkou do diskuse zůstává, do jaké míry jsou výsledky subjektivní i po jejich kvantifikaci (Chráska, 2007).

V České republice se výzkum environmentální gramotnosti a jejích složek orientuje na různé segmenty populace, přičemž mezi nejčastějšími cílovými skupinami respondentů dominují žáci základních a studenti středních škol (Činčera \& Štěpánek, 2007; Kroufek et al., 2016a). Kulich \& Dobiášová (2003) u této skupiny upozornili především na nízkou úroveň proenvironmentálních postojů a znalostí. Schovajsová (2010) se pak soustředila pouze na žáky základních škol, respektive na žáky škol s environmentálním zaměřením v porovnání $s$ žáky ze škol standardních. Mezi vědomostmi, postoji a chováním respondentů ovšem nebyly zjištěny signifikantní rozdíly. Hromádka (2010) zaznamenal slabou vazbu mezi environmentálními vědomostmi a postoji, stejně jako mezi postoji a chováním žáků základních škol. Činčera \& Štěpánek (2007) se věnovali proenvironmentálním postojům středoškolských studentů, přičemž neprokázali významnější rozdíly mezi postoji studentů prvních a čtvrtých ročníků. Při jejich zjištování aplikovali kombinaci rozšířené škály NEP - Nové ekologické

\footnotetext{
${ }^{1}$ Roztř́štěnosti a odlišnostem ve vnímání pojmů environmentální gramotnost, ekologická gramotnost a ekogramotnost a pojetí jejich vzájemného vztahu v České republice (Kroufek, 2016) se v tomto textu blíže nevěnujeme, tudíž tyto pojmy dále nerozlišujeme.
} 
paradigma (Dunlap et al., 2000) a škály zvažovaného proenvironmentálního jednání (Cordan et al., 2003). Obdobný výzkumný nástroj použili při porovnávání environmentálních postojů a jednání středoškolských studentů škol se zaměřením a bez zaměření na environmentální tematiku Bezouška \& Činčera (2007). Vztahem žáků druhého stupně základních škol a jejich rodičů k př́rodě se zabývali Vacínová \& Matějček (2013), při šetření využili výzkumný nástroj strukturovaný podle jednotlivých rovin osobního vztahu k prírodě (Krajhanzl, 2009); v tomto výzkumu se u žáků projevil poměrně nízký zájem o kontakt s prírodním prostředím. Výzkumy orientované na posouzení vlivu konkrétních aspektů environmentální výchovy a úrovně ekogramotnosti učitelů na environmentální gramotnost žáků druhého stupně základní školy realizovala Svobodová (2013; 2016).

Za atraktivní Ize z hlediska rozmanitosti použitých výzkumných nástrojů považovat studie cílené na vysokoškolské studenty. Kroufek \& Chytrý (2015) u nich zjištovali vztah k prírodě pomocí škály Nature relatedness (Nisbet et al., 2009). Badatelské dovednosti studentů, tedy kompetenční aspekt environmentální gramotnosti, sledovaly Dvořáčková \& Ryplová (2012), afektivní dimenzi se zase věnovali Matějček \& Bartoš (2012) a Kroufek (2013). Studenti učitelství či učitelé patř́ k oblíbeným respondentům také v zahraničí, např. na environmentálně odpovědné jednání studentů učitelství v Izraeli se zaměřili Goldman et al. (2006) a Pe'er et al. (2007). Hsu \& Roth (1998; 1999) a Shiang-Yao et al. (2015) směřovali svou pozornost na učitele základních a středních škol $v$ Tchajwanu, přičemž porovnávali úroveň jejich environmentální gramotnosti.

Za jeden z nejznámějších zahraničních výzkumných nástrojů pro komplexní měření environmentální gramotnosti u konkrétní věkové skupiny je považován MSELS - Middle School Environmental Literacy Survey (McBeth \& Volk, 2000). Jedná se o soubor testů a dotazníků sestávajících celkem ze 75 položek a zaměřených na zjištóování environmentálních znalostí, postojů, senzitivity, dovedností $k$ analýze a následnému efektivnímu řešení environmentálních problémů včetně odhodlání k proenvironmentálnímu jednání a deklarovanému chování. Současný MSELS je využíván např. v USA v rámci národního výzkumu environmentální gramotnosti žáků šesté a deváté třídy. $V$ českých podmínkách ovšem nebyl dosud tento nástroj etablován v plném rozsahu (Schovajsová, 2010).

Porozumění ekologickým konceptům, respektive ekologické znalosti, se v původní podobě MSELS měří jednoduchým testem se 17 položkami, $v$ nichž respondent volí vždy pouze jednu správnou odpověd' ze čtyř možností. Škála byla opakovaně přeložena a ověřena na žácích základní školy v České republice. Při ověřování modifikované škály v rámci projektu TAČR „Hodnocení efektivity nástrojů environmentálního vzdělávání, výchovy a osvěty (EVVO)" byla sice prokázána poměrně nízká náročnost testu pro starší respondenty, výsledky ale ukázaly, že se jedná o nástroj akceptovatelný z hlediska reliability. Ideální věkovou skupinou pro získání sofistikovaných výsledků ohledně vyšší úrovně ekologických znalostí s využitím daného testu jsou tedy žáci ve věku 9-12 let (Činčera, 2013b).

Z nástrojů používaných k měření environmentálních postojů Ize za nejznámější považovat NEP - Nové ekologické paradigma (Dunlap et al., 2000; Dunlap, 2008), který však má své limity (Lalonde \& Jackson, 2002; Kroufek et al., 2016c). Zajímavou alternativou je dvoudimenzionální škála 2-MEV² (J ohnson \& Manoli, 2008). J de o dvoufaktorový model environmentálních hodnot složený ze dvou přístupů k životnímu prostředí, antropocentrického a biocentrického, přičemž graficky Ize tyto dimenze vyjádřit jako $k$ sobě vzájemně kolmé a postavení jedince $v$ rámci každé $z$ nich je navzájem nezávislé, přičemž je sledována závislost

\footnotetext{
${ }^{2}$ MEV - Model of Environmental Values (Bogner \& Wiseman, 2006), 2-MEV - 2 Major Environmental Values (Bogner et al., 2015)
} 
jedné dimenze na druhé (Bogner \& Wiseman, 1999, 2006; Wiseman \& Bogner, 2003). Dimenzi zobrazující rozsah ochoty respondenta chovat se $\mathrm{k}$ životnímu prostředí šetrně, podporovat jeho ochranu, a vyjádření míry radosti z pobytu v prírodě představují položky faktoru Ochrana. Faktor Využívání je zastoupen položkami objasňujícími míru souhlasu respondenta se změnami životního prostředí ve prospěch potřeb lidské společnosti a s názorem, že člověk má právo ovládat př́rodu (Činčera, 2013a). Uvedené hlavní faktory, respektive jejich položky, byly dále na základě několika výzkumů, které realizovali za účelem ověření nástroje a jeho širšího přijetí především autoři modelu (Bogner et al., 2000; Wiseman \& Bogner, 2003; Wiseman et al., 2012), rozpracovány do dalších dílčích faktorů. Faktor Ochrana tak nyní tvoři tyto části: odhodlání k podpoře, péče o zdroje a radost z přírody, faktor Využívání: měnění prírody a dominance (Činčera, 2013a).

Proces vzniku současné verze 2-MEV škály byl komplikovaný a náročný (Činčera, 2013a). Aktuální podoba vychází původně ze škály ENV (Bogner \& Wiseman, 1999), následně z výzkumného nástroje TEQ - The Environmental Questionaire (Johnson \& Manoli, 2008), jenž je tvořen položkami ze škál ENV a NEP. Tento nástroj autoři dále upravili $v$ souladu s modelem MEV a později jej začali aplikovat pod názvem 2-MEV (J ohnson \& Manoli, 2011). Mnozí výzkumníci (J ohnson \& Manoli, 2011; Liefländer \& Bogner, 2014) použili škálu především k evaluaci programů EVVO pro děti a dospívající nejenom $v$ zahraničí, ale po jeho překladu i v českých podmínkách (Činčera \& Johnson, 2013). Kvalita nástroje byla ověřena také na dospělých respondentech, kdy byla potvrzena jeho funkčnost a přijatelná reliabilita (Munoz et al., 2009; Kroufek et al., 2015).

Tento výzkumný text tematicky navazuje na studii Svobodové \& Kroufka (2016) a snaží se dále rozšiřit povědomí o možnostech měření environmentální gramotnosti u cílové skupiny žáků druhého stupně základní školy. $\mathrm{S}$ pomocí výše popsaných nástrojů $v$ něm budeme hledat odpovědi na následující výzkumné otázky:

Jaký je u respondentů vztah mezi environmentálními vědomostmi a postoji?

Jaký vliv mají na environmentální vědomosti a postoje vybrané demografické proměnné (pohlaví, věk, navštěvovaný ročník, bydliště)? dentů?

Jaký vliv mají na environmentální vědomosti a postoje volnočasové aktivity respon-

\section{Metodologie}

Respondenty byli žáci 6.-9. ročníků druhého stupně Základní školy Žatec, nám. 28. října 1019, okres Louny $(N=87)$. Šetření se účastnilo 42 dívek a 45 chlapců. Nezbytnou součást dotazníku byly také demografické údaje o respondentovi.

Výzkumný nástroj (viz Příloha 1) je složen ze dvou částí. Ekologické znalosti byly zjištovány pomocí vědomostního testu MSELS ${ }^{3}$ sestaveného ze 17 položek vždy s jednou správnou odpovědí ze čtyř možností (Činčera, 2013b). Environmentální postoje byly měěeny $\mathrm{s}$ využitím dvoudimenzionální škály $2-$ MEV$^{4}$ (J ohnson \& Manoli, 2008) se 16 položkami, u nichž respondenti zaznamenávali míru souhlasu na pětibodové Likertově škále (souhlasím - spíš

3 Český překlad Schovajsová (2010)

${ }^{4}$ Český překlad Činčera (2013a) 
souhlasím - nevím - spíš nesouhlasím - nesouhlasím). U faktoru Ochrana byly jednotlivé odpovědi bodovány hodnotami 5 za souhlas až 1 za nesouhlas. Vzhledem $k$ tomu, že dimenze Ochrana sestává z devíti položek, mohli respondenti získat maximálně 45 a minimálně 9 bodů. U faktoru Využívání, sestávajícího ze sedmi položek, u nichž znamenal souhlas odklon od pozitivního environmentálního postoje, bylo bodování reverzní, tudíž mohl každý respondent obdržet maximálně 35 a minimálně 7 bodů. S ohledem na odlišný počet položek u jednotlivých dimenzí Ize předpokládat při grafickém znázornění výsledků rozdílné měřítko na ose y.

Reliabilita MSELS $(a=0,67)$ i 2-MEV $(a=0,71)$ je vzhledem k nízkému počtu respondentů vyhovující a tyto dva nástroje je tak možné považovat pro potřeby představovaného výzkumu za akceptovatelné. Totéž Ize tvrdit také pro jednotlivé subškály nástroje 2-MEV, Ochrana, faktor vyjadřující ochotu respondenta chránit přírodu, $(a=0,70)$ a Využívání, faktor vyjadřující souhlas respondenta s využíváním prírody člověkem, $(a=0,62)$.

Zjištěná data byla analyzována standardními statistickými metodami programem Statistica 12 (Statsoft, 2015).

Pomocí Shapiro-Wilkova testu byla testována normalita rozložení získaných dat. V případě vědomostí $(W=0,97 ; p=0,055)$ a faktoru Využívání $(W=0,98 ; p=0,299)$ nelze odmítnout nulovou hypotézu o normálním rozložení dat a při zpracování výsledků těchto dvou škál jsou použity parametrické metody statistické analýzy - T-test a ANOVA. U dvoudimenzionální škály 2-MEV jako celku $(W=0,96 ; p=0,009)$ a faktoru Ochrana $(W=0,95$; $\mathrm{p}=0,001)$ přijímáme alternativní hypotézu a při analýze jejích výsledků budou využity metody neparametrické - Spearmanův korelační koeficient, Man-Whitney U test a Kruskal-Wallisova ANOVA.

Studie je sice založena na relativně nízkém počtu respondentů a záměrném výběru, získaná zjištění tedy nelze generalizovat na celou cílovou skupinu žáků 2 . stupně Zš. Jedná se o práci, jejímž cílem je testovat metodologii a ověřit její možné př́nosy.

\section{Výsledky}

K identifikaci vzájemných vztahů mezi vybranými aspekty environmentální gramotnosti - vědomostmi a postoji - byl použit Spearmanův korelační koeficient, vypočtené hodnoty jsou uvedeny $v$ Tabulce 1 . Co se týče korelací mezi environmentálními vědomostmi a postoji respondentů, Ize alternativní hypotézu přijmout $v$ př́padě vztahu mezi vědomostmi a škálou 2-MEV $(\rho=0,35)$ a vědomostmi a subškálou Využívání $(\rho=0,42)$, effect size uvedených poměrů je však velmi malý $\left(\rho^{2}=0,12 ; \rho^{2}=0,18\right)$.

Výpočty také prokázaly kladnou pozitivní korelaci obou faktorů, Ochrana a Využívání, s dvoudimenzionální škálou 2-MEV (dimenze Ochrana $\rho=0,72$; dimenze Využívání $\rho=$ $0,73)$. 
Tabulka 1 - Vztah mezi environmentálními vědomostmi a postoji

\begin{tabular}{ccccc}
\hline & Vědomosti & 2-MEV & Ochrana & Využívání \\
\hline \hline Vědomosti & & $\mathbf{0 , 3 5}$ & 0,10 & $\mathbf{0 , 4 2}$ \\
2-MEV & $\mathbf{0 , 3 5}$ & & $\mathbf{0 , 7 2}$ & $\mathbf{0 , 7 3}$ \\
Ochrana & 0,10 & $\mathbf{0 , 7 2}$ & & 0,12 \\
Využívání & $\mathbf{0 , 4 2}$ & $\mathbf{0 , 7 3}$ & 0,12 & \\
\hline
\end{tabular}

Tučně zvýrazněné hodnoty jsou statisticky významné na hladině $p<0,05$

Rozsah vlivu vybraných demografických proměnných (pohlaví, věk, navštěvovaný ročník, bydliště) byl zjištován u jednotlivých škál výzkumného nástroje samostatně.

\section{Pohlaví}

Co se týče environmentálních vědomostí, dosáhly vyšších hodnot dívky (viz Graf 1 ), ovšem nejedná se o výsledek statisticky významný $(t=1,07 ; p=0,287)$ a nelze zamítnout nulovou hypotézu.

Graf 1 - Environmentální vědomosti - porovnání výsledků dle pohlaví

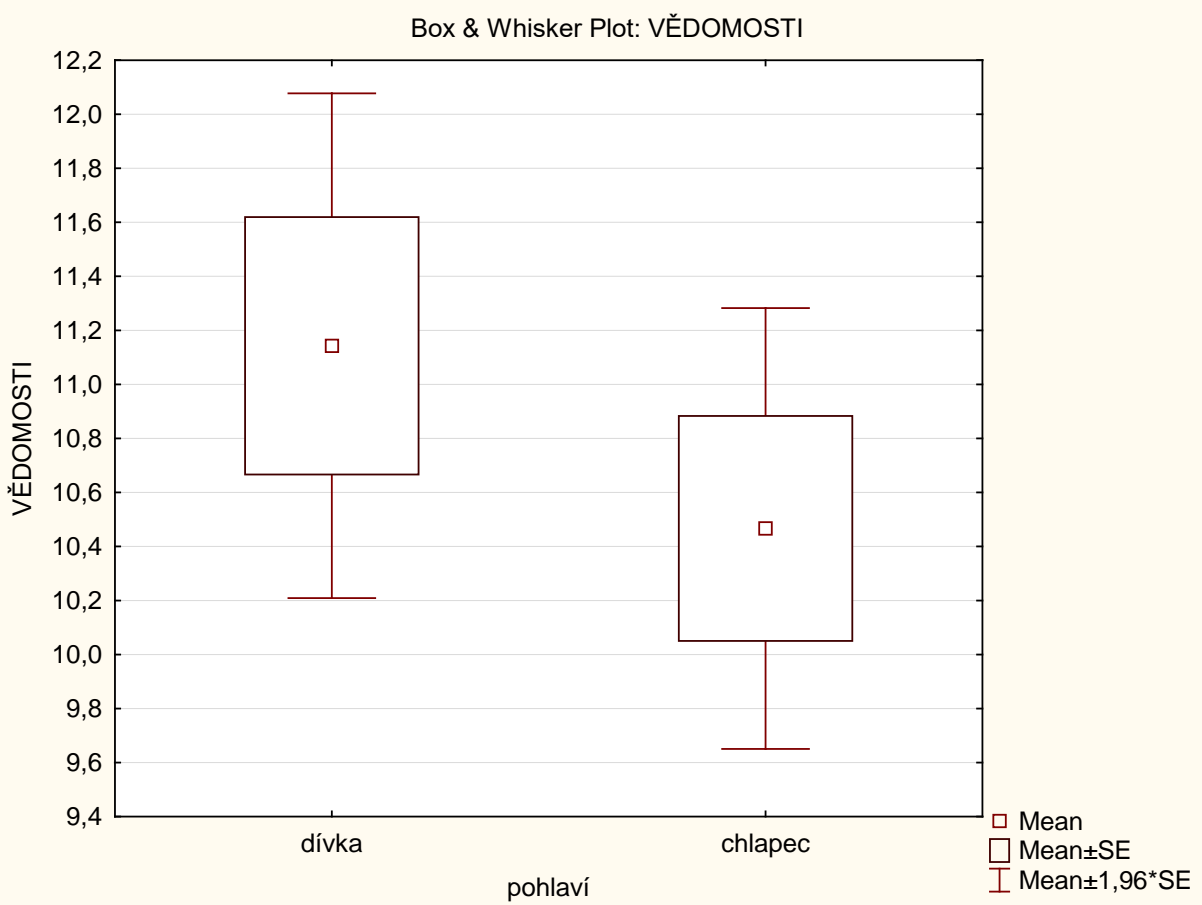


V prípadě proenvironmentálních postojů nebyl také prokázán statisticky významný vliv pohlaví na jejich úroveň. Podobně jako u škály 2 - $M E V(Z=-0,985 ; p=0,324)$, nelze ani $u$ jedné ze subškál Ochrana $(Z=-1,546 ; p=0,122)$ a Využívání $(t=-0,042 ; p=0,966)$ zamítnout nulovou hypotézu.

\section{Věk}

Také míra vlivu věku respondentů, respektive navštěvovaného ročníku, na zjištěné hodnoty sledovaných složek environmentální gramotnosti byla vyhodnocena pro každou škálu výzkumného nástroje zvlášt́. Minimální variabilitu napříc navštěvovanými ročníky ( $F=$ $0,357 ; p=0,783)$, kdy nelze zamítnout nulovou hypotézu, vykázala oblast environmentálních vědomostí.

Co se týče závislosti hodnot získaných pomocí škály 2-MEV $(H=8,7 ; p=0,033)$ na věku respondentů, Ize přijmout alternativní hypotézu o statisticky významném vlivu ročníku. Lze tedy předpokládat (viz Graf 2 ), že se stoupajícím ročníkem základní školy signifikantně klesají hodnoty afektivní složky environmentální gramotnosti.

Graf 2 - 2-MEV, postoje - porovnání výsledků dle ročníku

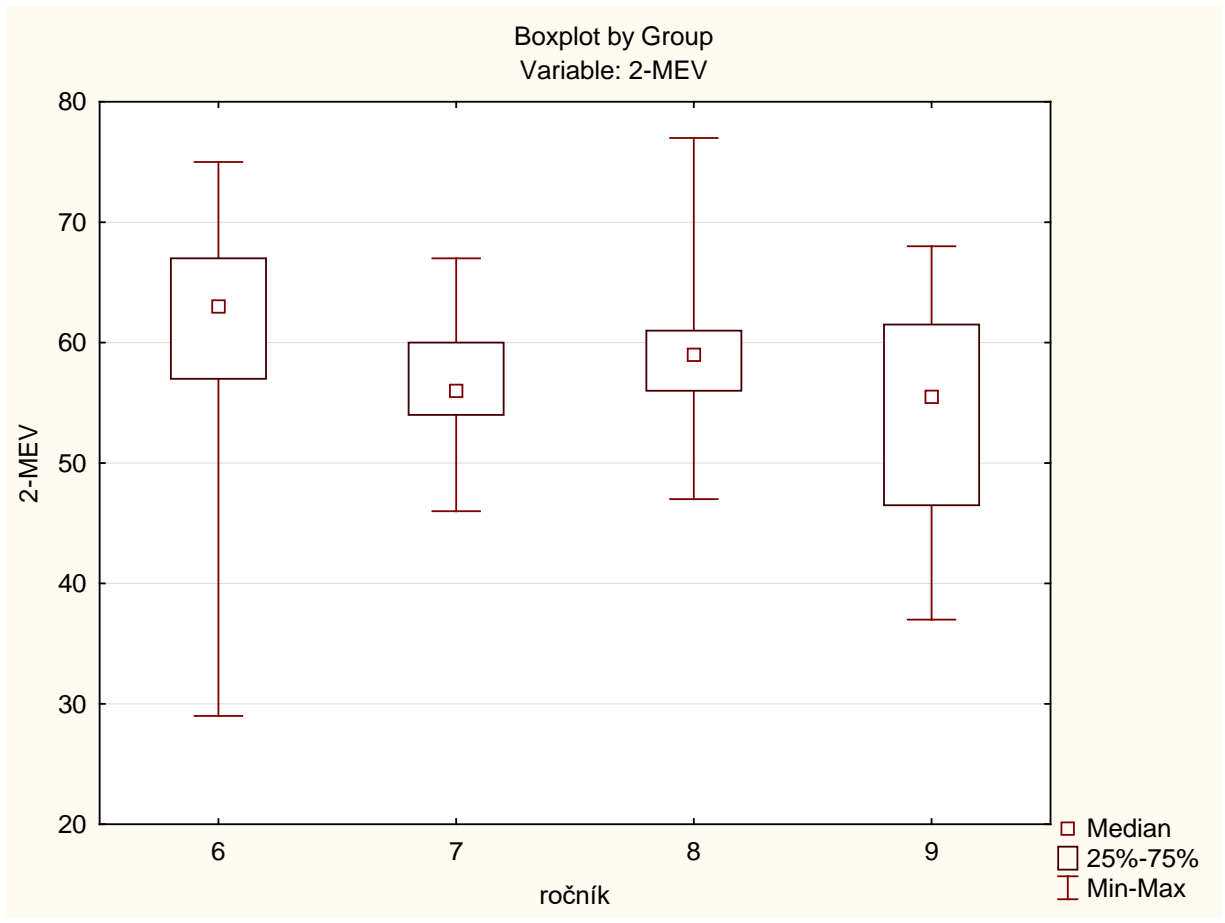

Škála 2-MEV je ovšem dvoudimenzionální, přičemž obě dimenze jsou na sobě nezávislé (J ohnson \& Manoli, 2008). Porovnání vlivu věku respondentů v rámci jednotlivých subškál Ochrana a Využívání přineslo ovšem protikladné výsledky.

$\checkmark$ prípadě faktoru Ochrana nelze zamítnou nulovou hypotézu $(H=3,4 ; p=0,33)$, tudíž vliv věku respondentů, respektive navštěvovaného ročníku základní školy, na postoje $\checkmark$ oblasti ochrany není statisticky významný. 
Naopak $v$ př́padě faktoru Využívání $(F=3,718 ; p=0,015)$ přijímáme alternativní hypotézu, věk respondentů Ize tedy považovat za statisticky významnou proměnnou (viz Graf 3). Následná post hoc analýza ukázala tři kombinace ročníků, mezi kterými byl nalezen signifikantní rozdíl, a to mezi 6 . a 7. ročníkem $(p=0,02), 7$. a 8. ročníkem $(p=0,007)$ a 8 . a 9. ročníkem $(p=0,023)$. $V$ rámci analýzy se nejvýrazněji projevil osmý ročník, který se statisticky významně lišil od dvou ostatních, 7. a 9. ročníku.

Vzhledem k nízkému počtu respondentů a jejich záměrnému výběru však nelze daná zjištění jednoduchým zpưsobem zobecňovat na celou cílovou skupinu.

Graf 3 - Postoje, dimenze Využívání - porovnání výsledků dle ročníku

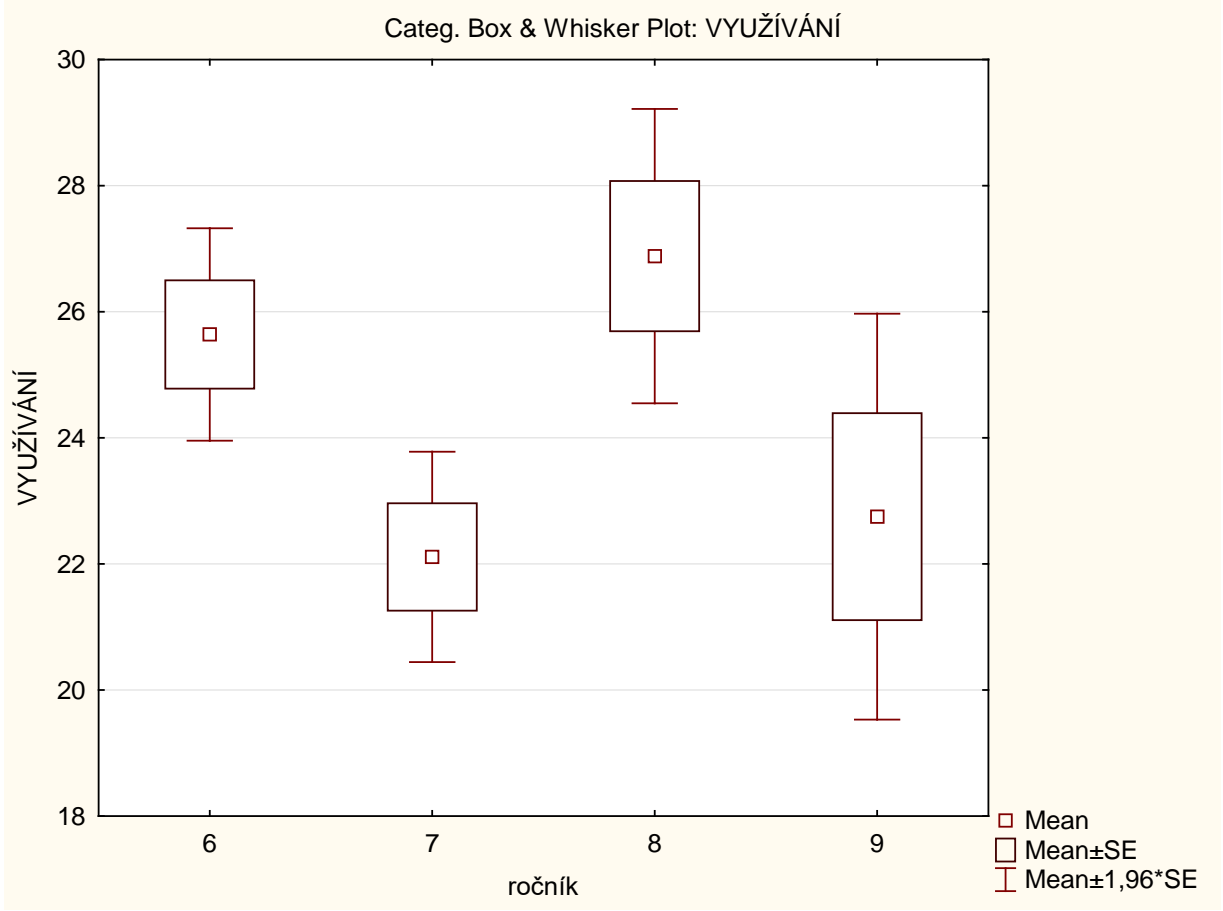

\section{Bydliště}

Obdobně jako pro proměnné pohlaví a věk respondentů byla i pro proměnnou bydliště vyhodnocena každá škála výzkumného nástroje samostatně, nicméně ani u jedné $z$ nich nelze zamítnout nulovou hypotézu, tedy nejenom $v$ př́padě škály environmentálních vědomostí ( $t=1,279 ; p=0,204)$, ale také u postojové dvoudimenzionální škály 2 - MEV ( $Z=$ $0,999 ; p=0,317)$, stejně jako u subškál Ochrana $(Z=1,233 ; p=0,217)$ a Využívání $(t=$ $0,023 ; p=0,982)$. $\vee$ oblasti environmentálních vědomostí dosahovali sice respondenti žijící ve městě vyšších hodnot než ti z vesnic, avšak uvedená zjištění nelze ani tak považovat za statisticky významná.

\section{Volnočasové aktivity}

Také v případě volnočasových aktivit bylo srovnání rozsahu vlivu jednotlivých činností zpracováno samostatně pro každou ze sledovaných složek environmentální gramotnosti. V oblasti environmentálních vědomostí vykazovaly sice volnočasové aktivity vyšší variabilitu $(F=1,468 ; p=0,229)$, ale opět se nejedná o statisticky významné zjištění a nelze zamítnout nulovou hypotézu. 
Naopak jako statisticky významná se jeví vzájemná závislost mezi jednotlivými volnočasovými aktivitami respondentů a proenvironmentálními postoji v rámci nástroje 2-MEV $(\mathrm{H}=8,818 ; \mathrm{p}=0,032)$, kdy Ize přijmout alternativní hypotézu o významném vlivu této proměnné na afektivní aspekt environmentální gramotnosti. Pobyt $v$ př́rodě a sport se prokázaly jako aktivity s nejvyšším pozitivním vlivem na postoje respondentů.

Totožné tendence Ize pozorovat také u dimenze Ochrana, kdy Ize opět považovat vliv volnočasových aktivit za statisticky významný $(H=8,66 ; p=0,034)$, a tudíž přijmout alternativní hypotézu, přičemž nejvýraznější kladný vliv se projevil taktéž u pobytu v přírodě a sportu (viz Graf 4).

Graf 4 - Postoje, dimenze Ochrana - porovnání výsledků dle volnočasové aktivity

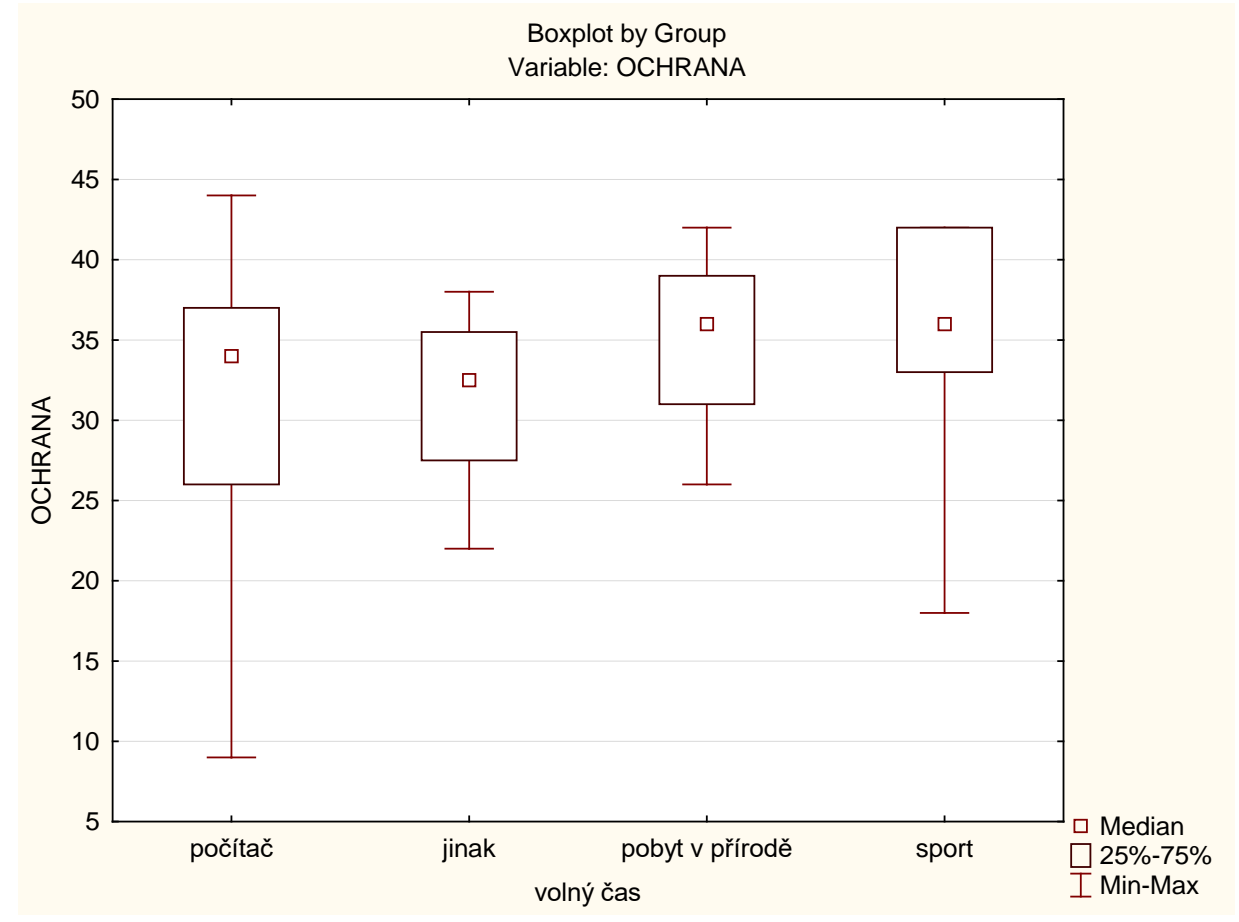

Obdobně byl pozitivní vliv pobytu v prírodě a sportu oproti jiným aktivitám na proenvironmentální postoje respondentů zaznamenán také u dimenze Využívání (viz Graf 5), ovšem v tomto prípadě nejsou zjištění statisticky významná $(F=0,768 ; p=0,515)$ a nelze zamítnout nulovou hypotézu.

Ani v př́padě volnočasových aktivit nelze s ohledem na malou velikost výzkumného vzorku výše uvedená zjištění zobecňovat. 
Graf 5 - Postoje, dimenze Využívání - porovnání výsledků dle volnočasové aktivity

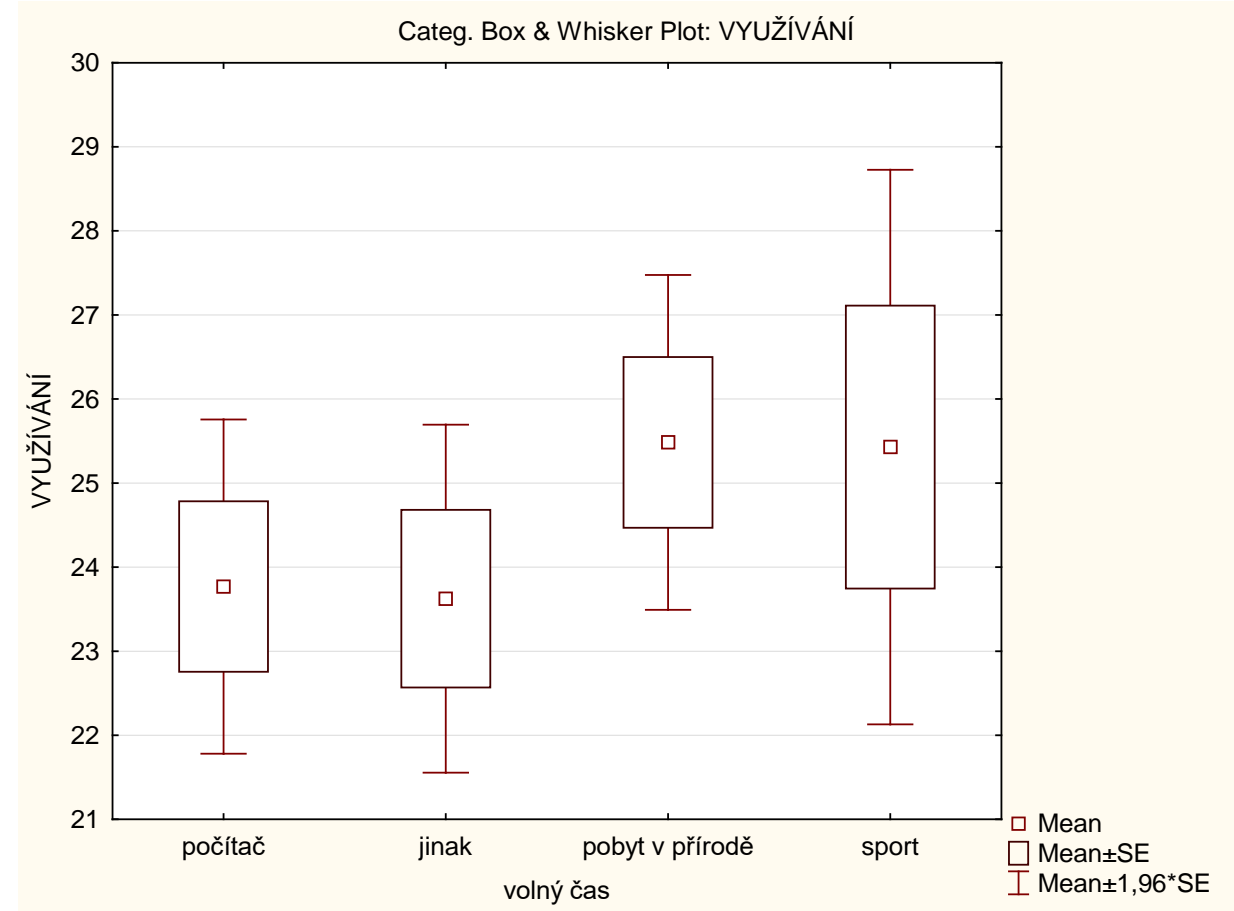

\section{Diskuse}

Prezentované šetření poskytuje několik zajímavých zjištění o vlivu vybraných sociodemografických proměnných na některé složky environmentální gramotnosti žáků 2 . stupně základní školy. Přestože nelze vzhledem k nízkému počtu respondentů uvedené výsledky většinou generalizovat na celou cílovou skupinu, často korespondují se zjištěními, které přinesly další výzkumy zaměřené na obdobnou problematiku.

Vzájemný vztah mezi kognitivní a afektivní složkou environmentální gramotnosti, respektive mezi environmentálními vědomostmi a postoji, se dle očekávání nepotvrdil jako statisticky významný. Korelace mezi vědomostmi a škálou 2-MEV, konkrétně faktorem Využívání, sice vykazovala pozitivní hodnoty, jednalo se ovšem o velmi slabou vazbu. Obdobný trend zaznamenal u žáků 8. a 9. ročníků základní školy také Hromádka (2010). Vliv kognitivního aspektu environmentální gramotnosti na postoje nebyl potvrzen ani u dospělých respondentů (Kroufek, 2016). Uvedené závěry se opět přiklánějí ke kritice modelu KAB (Ramsey \& Rickson, 1976), který předpokládá vzájemnou závislost mezi vědomostmi, postoji a chováním.

$\checkmark$ prípadě vlivu pohlaví na testované aspekty environmentální gramotnosti nebyl nalezen signifikantní rozdíl ani u jedné ze zkoumaných složek. $U$ environmentálních vědomostí sice dosahovaly dívky vyšších hodnot, výsledek ovšem nelze považovat za statisticky významný. $\mathrm{K}$ podobným závěrům ohledně minimálního vlivu pohlaví na afektivní složku environmentální gramotnosti dospěly také Sadiková \& Sadiková (2014). V porovnání s jinými autory (Tan, 2014; Kroufek et al., 2015), kteří naopak zjistili signifikantní rozdíl mezi pohlavím, Ize tuto proměnnou považovat za poměrně nestálou.

Na rozdíl od proměnné pohlaví přineslo testování vztahu mezi zkoumanými složkami environmentální gramotnosti a navštěvovaným ročníkem, respektive věkem respondentů, 
zajímavější zjištění. Jako signifikantní se ukázal vliv věku respondentů především v oblasti postojů, zvláště u faktoru Využívání, přičemž se projevil značnou variabilitou ročníků. Podobný trend, a sice klesající úroveň environmentálních postojů v souvislosti s rostoucím věkem žáků v období dospívání, zaznamenali Liefländer \& Bogner (2014). Naopak u dospělých respondentů se projevil opačný efekt (Kroufek, 2016), jindy nebyl vliv věku na postoje prokázán jako statisticky významný (Matějček \& Bartoš, 2012).

Obdobně jako $v$ prípadě pohlaví se ani vliv bydliště (vesnice vs. město) na vybrané složky environmentální gramotnosti neprojevil jako signifikantní. Naopak u dospělých respondentů, studentů učitelství, dospěli Kroufek (2016) nebo v Izraeli Goldmanová et al. (2006) ke zjištění, že velikost bydliště hraje důležitou roli ve vztahu k afektivnímu aspektu environmentální gramotnosti.

Vliv volnočasových aktivit respondentů se ukázal signifikantní pouze u afektivního aspektu, zvláště u faktoru Ochrana. $Z$ daných aktivit pozitivně ovlivňovaly výsledky především pobyt $v$ prírodě a sport. Kladný vztah mezi environmentálně laděnými aktivitami a postoji potvrzuje také Swanepoel et al. (2002).

\section{Závěr}

Cíl výše představené studie spočival v analýze vlivu některých sociodemografických proměnných na vybrané aspekty environmentální gramotnosti žáků druhého stupně Základní školy Žatec, nám. 28. ř́jna 1019, okres Louny. Studie se věnovala testování kognitivního aspektu environmentální gramotnosti, environmentálních vědomostí, a afektivního aspektu environmentální gramotnosti, proenvironmentálních postojů. Poměr mezi oběma zkoumanými aspekty byl prokázán jako nepř́liš těsný lineární vztah.

Analýza vlivu demografických proměnných neprokázala signifikantní vliv pohlaví stejně jako velikosti bydliště ani u jedné ze sledovaných složek environmentální gramotnosti. Při porovnání závislosti dle věku respondentů, respektive navštěvovaného ročníku, se projevil signifikantní vliv těchto proměnných pouze na proenvironmentální postoje, kdy lze pozorovat tendence mírného poklesu hodnot $s$ rostoucím věkem. $V$ případě vlivu volnočasových aktivit jsou závěry podobné, signifikantní vliv byl potvrzen opět pouze u postojů, přičemž nejvýrazněji se kladný vztah projevil jako důsledek aktivit zaměřených na pobyt $\mathrm{v}$ př́rodě a sport.

Generalizace interpretovaných výsledků na celou cílovou skupinu je sice značně omezena nereprezentativní povahou zkoumaného vzorku, ale přesto studie poskytuje několik zajímavých zjištění využitelných pro následné rozsáhlejší výzkumy zaměřené na problematiku testování environmentální gramotnosti, dílčích dimenzí ve vzájemných korelacích a analýzu vlivu konkrétních sociodemografických proměnných. Předložená studie např́íklad naznačuje zajímavé tendence ohledně možného determinujícího vlivu některých volnočasových aktivit $v$ oblasti environmentálních postojů.

Šetření zaměřená na environmentální gramotnost jsou velmi podstatná nejenom pro základní výzkumy v oblasti environmentální výchovy, ale slouží také $\mathrm{k}$ hledání cest efektivní evaluace. Mimo jiné Ize uvedenou studii považovat za významnou rovněž z hlediska ověření využitelnosti předložených výzkumných nástrojů, především dvoudimenzionální škály 2MEV. 


\section{Seznam použité literatury}

- $\quad$ Andrews, K. E., Tressler, K. D. \& Mintzes, J. J. (2008). Assessing environmental understanding: an application of the concept mapping strategy. Environmental Education Research, 14,5,519-536.

- Bezouška, A., \& Činčera, J. (2007). Vliv environmentální profilace středních škol na proenvironmentální postoje a jednání studentů. Envigogika, 2(3). doi: 10.14712/18023061.20

- Bogner, F. X., \& Wiseman, M. (1999). Toward Measuring Adolescent Environmental Perceprion. European Psychologist, 4(3), 139-151. doi: 10.1027//10169040.4.3.139

- Bogner, F. X., \& Wiseman, M. (2002). Environmental perceprion: Factor profiles of extreme groups. European Psychologist, 7(3), 225-237. doi: 10.1027//10169040.7.3.225

- Bogner, F. X., \& Wiseman, M. (2006). Adolescents' attitudes towards nature and environment: Quantifying the 2-MEV model. Environmentalist, 26(4), 247-254. doi: $10.1007 /$ s10669-006-8660-9

- Bogner, F. X., Brengelmann, J. C., \& Wiseman, M. (2000). Risktaking and environmental perception. The Environmentalist, 20(1), 49-62.

- Bogner, F. X., Johnson, B., Buxner, S., \& Felix, L. (2015). The 2-MEV model: Constancy of adolescent environmental values within an 8year time frame. International J ournal of Science Education, 37(12), 1938-1952. doi: 10.1080/09500693.2015.1058988

- Bronven, D., Stanisstreet, M., \& Boyes, E. (2004). How can we best reduce gobal waming? School students' ideas'and misconceptions. International Journal of Environmental Studies, 61(2), 211-222. doi: 10.1080/0020723032000087907

- Bragg, R., Wood, C, Barton, J., \& Pretty, J. (2013). Measuring connection to nature in children aged 8 - 12: A robust methodology for the RSPB. University of Essex: $64 \mathrm{~s}$.

- Cordano, M., Welcomer, S. A., \& Scherer, R. F. (2003). An Analysis of the Predictive Validity of the New Ecological Paradigm Scale. The Journal of Environmental Education, 34(2), 22-28. doi: 10.1080/00958960309603490

- CČinčera, J. \& Štěpánek, P. (2007). Výzkum ekologické gramotnosti studentů středních odborných škol. Envigogika, 2(1). doi: 10.14712/18023061.12

- Činčera, J., \& Johnson, B. (2013). Earthkeepers in the Czech Republic: Experience from the implementation process of an earth education programme. Envigogika, 8(4). doi: 10.14712/18023061.397

- CČinčera, J. (2007). Environmentální výchova: od cílů k prostředkưm. Paido, Brno. ISBN 978-80-7315-147-8.

- Činčera, J. (2009). Analýza průřezového tématu Environmentální výchova v Rámcovém vzdělávacím programu pro základní vzdělávání. Envigogika, 4(1). doi: $10.14712 / 18023061.36$ 
- Činčera, J. (2011). Doporučené očekávané výstupy pro environmentální výchovu. Envigogika, 6(2). doi: 10.14712/18023061.59

- Činčera, J. (2013). Paradigmatická proměna domácího pojetí environmentální výchovy. Pedagogika, 2013(2), 182-197.

- Činčera, J. (2013a). Metodika pro hodnocení environmentální výchovy pro předškolní a mladší školní věk. Envigogika, 8(5). doi: 10.14712/18023061.413

- Činčera, J. (2013b). Metodika pro hodnocení environmentální výchovy pro starší školní věk a střední školy. Envigogika, 8(5). doi: 10.14712/18023061.414

- Činčera, J., Kroufek, R., Šimonová, P., Broukalová, L., Broukal, V., \& Skalík, J. (2015). Eco-School in Kindergartens: The Effects, Interpretation and Implementation of a Pilot Program. Environmental Education Research. [article in press] doi: $10.1080 / 13504622.2015 .1076768$

- Daniš, P. (2013). Nové vymezení environmentální gramotnosti a návrh na její mezinárodní testování v PISA 2015. Envigogika, 8(3). doi: 10.14712/18023061.385

- Dunlap, R. E. (2008). The New environmental paradigm scale: From marginality to worldwide use. The Journal of Environmental Education, 40(1), 3-18. doi: 10.3200/joee.40.1.3-18

- Dunlap, R. E., Van Liere, K. D., Mertig, A. G., \& Jones, R. E. (2000). Measuring endorsement of the New Ecological Paradigm: a revised NEP scale. The J ournal of Social Issues, 56(3), 425-442. doi: 10.1111/0022-4537.00176

- Dvořáčková, S., \& Ryplová, R. (2012). Sonda environmentální gramotnosti studentů prírodovědně a ekologicky zaměřených oborů na Pedagogické fakultě jU. Envigogika 7(3). doi: 10.14712/18023061.77

- Edoğan, N. (2009). Testing the new ecological paradigm scale: Turkish case. African Journal of Agricultural Research, 4(10), 1023-1031.

- Franěk, M. (2012). Nature Relatedness Scale. Český překlad škály měříí spojení s prírodou. Envigogika, 7(1). doi: 10.14712/18023061.69

- Goldman, D., Yavetz, B., \& Pe'er, S. (2006). Environmental Literacy in Teacher Training in Israel: Environmental Behavior of New Students. The J ournal of Environmental Education 38(1), 3-22. doi: 10.3200/joee.38.1.3-22

- Gul, S., \& Yesilyurt, S. (2011). A Study on Primary and Secondary School Students' Misconceptions abou Greenhouse Effect (Erzurum Sampling). International Electronic J ournal of Environmenal Education, 1(3), 193-202.

- Hollweg, K. S. Taylor, J. R., Bybee, R. W., Marcinkowski, T. J., McBeth, W. C., \& Zoido, P. (2011). Developing a framevork for assessing environmental literacy. Washington, DC: North American Association for Environmental Education.

- Hromádka, Z. (2010). Životní prostředí ve vědomostech, postojích a jednání žáků druhého stupně základní školy. Disertační práce, Brno: Masarykova univerzita, Pedagogická fakulta, $164 \mathrm{~s}$. 
- Hsu, S. J., \& Roth, R. E. (1998). An Assessment of Environmental Literacy and Analysis of Predictors of Responsible Environmental Behaviour Held by Secondary Teachers in the Hualien Area of Taiwan. Environmental Education Research, 4(3), 229-249. doi: 10.1080/1350462980040301

- Hsu, S. J., \& Roth, R. E. (1999). Predicting Taiwanese Secondary Teachers' Responsible Environmental Behavior Through Environmental Literacy Variables. The J ournal of Environmental Education, 30(4), 11-18. doi: $10.1080 / 00958969909601879$

- Hungerford, H. R., Volk, T., Wilke, R., Champeau, R., Marcikowski, T., May, T., Bluhm, W., \& McKeown-Ice, R. (1994). Environmental literacy Framework. Environmental Education Literacy Consorcium, University of South Illiois.

- Chráska, M. (2007). Metody pedagogického výzkumu. Základy kvantitativního výzkumu. Praha: Grada, 265 s.

- Jančaříková, K. (2007). Úcta k živoru: jeden z cílů Environmentální výchovy v Rámcovém vzdělávacím programu a dokážeme se s ní ve školní praxi vypořádat? Envigogika, 2(2). doi: 10.14712/18023061.2007.2.2

- Jeffries, H., Stanisstreet, M., \& Boyes, E. (2001). Knowledge about the Greenhouse Effect: Have college students iproved? Research in Science and Technological Education, 19(2), 205-221. doi: 10.1080/02635140120087731

- Johnson, B., \& Manoli, C. C. (2008). Using Bogner and Wiseman's Model of Ecological Values to measure the impact of an earth education programme on children's environmental perceptions. Environmental Education Research, 14(2), 115-127. doi: $10.1080 / 13504620801951673$

- Johnson, B., \& Manoli, C. C. (2011). The 2-MEV scale in the US: A measure of children's environmental attitudes based on the theory of ecological attitude. Journal of Environmental Education, 42(2), 84-97. doi: 10.1080/00958964.2010.503716

- Krajhanzl, J. (2009). Člověk + Př́roda = Udržitelnost? Texty o proměně vztahư lidí k prírodě, environmentální výchově a udržitelnosti. Praha: Zelený kruh, 2-7.

- Kroufek R. (2013): Environmentální postoje studentů učitelství pro 1. stupeň ZŠ. XXI. celostátní konference ČAPV Efektivita vzdělávání v proměnách společnosti. PF UJ EP, Ústí nad Labem. ISBN 978-80-7414-602-2, 431-435.

- Kroufek, R. (2016). Environmentální gramotnost studentů Učitelství pro 1. stupeň základní školy a možnosti jejího zjištování. Disertační práce, PF JU, České Budějovice. doi: 10.13140/RG.2.1.3858.0724

- Kroufek, R. \& Chytrý, V. (2015). The Nature Relatedness of the Undergraduate Students in the Czech Republic. ICERI2015 proceedings, Seville: 7479-7483. ISBN 978-84-608-2657-6, ISSN 2340-1096

- Kroufek, R., Janovec, J., \& Chytrý, V. (2015). Pre-service primary teachers and their attitudes towards nature. In: Fleischmann, O., Seebauer, R., Zoglowek, H., \& Aleksandrovich, M. [eds.] The Teaching profession: New Challneges - New Identities. Lit Verlag GmbH \& Co. KG, Wien. 
- Kroufek, R., Chytrý, V., Janovec, J. \& Brtnová Čepičková, I. (2016a). Effect of leisure activities on responsible environmental behaviour of pupils of primary school. ICERI 2016 proceedings. 7451-7456. doi: 10.21125/iceri.2016.0703

- Kroufek, R., Janovec, J. Chytrý, V., \& Simonová, V. (2016b). Connection to Nature among kindergarten children and their parents. INTED 2016 proceedings. Valencia: IATED.

- Kroufek, R., Chytrý, V., J anovec, J. \& Brtnová-Čepičková, I. (2016c). The Use of New Ecological Paradigm Scale among Pre-service Primary Teachers: limits and possibilities. INTCESS 2016 proceedings: 534-540. ISBN 978-605-64453-5-4

- Kulich, J., \& Dobiášová, M. (2003). Průzkum ekogramotnosti. Bedrník, př́loha časopisu $1(2)$.

- Lalonde, R., \& Jackson, E. L. (2002). The New Environmental Scale: Has It Outlived Its Usefulness? J ournal of Environmental Education, 33(4), 28-36. doi: $10.1080 / 00958960209599151$

- Liefländer, A. K., \& Bogner, F. X. (2014). The effects of children's age and sex on acquiring proenvironmental attitudes through environmental education. The Journal of Environmental Education, 45(2), 105-117. doi:

$10.1080 / 00958964.2013 .875511$

- Matějček, T., \& Bartoš, J. (2012). Environmentální gramotnost učitelů a studentů učitelství. Envigogika, 7(2). doi: 10.14712/18023061.75

- Matějček, T., \& Vacínová, M. (2012). Environmentální gramotnost - výsledky výzkumu na pražských gymnáziích. Geografické rozhledy, 22(1), 16-17.

- Mcbeth, W., \& Volk, T. L. (2010). The National Environmental Literacy Project: A baseline study of middle grade students in the United States. The J ournal of Environmental Education, 41,1,55-67.

- MŠMT (2001). Národní program rozvoje vzdělávání v České republice - Bílá kniha. Praha: MŠMT, $98 \mathrm{~s}$.

- MŠMT (2013). Rámcový vzdělávací program pro základní vzdělávání. Praha: MŠMT, $146 \mathrm{~s}$.

- MŽP (2011). Cíle a indikátory pro environmentální vzdělávání, výchovu a osvětu v České republice. Praha: MŽP, 16 s.

- Munoz, F., Bogner, F., Clement, P., \& Calvalho, G. S. (2009). Teachers' conceptions of nature and environment in 16 countries. Journal of Environmental Psychology, 24(3), 289-303. doi: 10.1016/j.jenvp.2009.05.007

- Nisbet, E. K., Zelenski, J. M., \& Murphy, S. A. (2009). The Nature relatedness scale. Linking individuals' connection with nature to environmental concern and behavior. Environment and Behavior, 41(5), 715-740. doi: $10.1177 / 0013916508318748$

- Nisbet, E. K., \& Zelenski, J. M. (2013). The NR-6: a new brief measure of nature relatedness. Frontiers in Psychology, 4, 1-11. doi: 10.3389/fpsyg.2013.00813 
- Pastorová, M. et al. [eds.] (2011). Doporučené očekávané výstupy. Metodická podpora pro výuku průřezových témat $v$ gymnáziích. Praha: Výzkumný ústav pedagogický. Dostupné na: http://www. vuppraha.cz/wp-content/uploads/2011/10/Doporucene_ocekavane_-vystupy_-gymnazia.pdf [cit. 11. 1. 2017]

- Pe'er, S., Goldman, D., \& Yavetrz, B. (2007). Environmental literacy in teacher training: Attitudes, knowledge and environmental beavior of beginning students. The J ournal of Environmental Education, 39(1), 45-59. doi: 10.3200/joee.39.1.45-59

- Penuel, W. R., Bienkowski, M., Gallagher, L., Korbak, C., Sussex, W., Yamaguchi, R. \& Fishman, B. J. (2006). GLOBE Year 10 evaluation: Into the next generation. Menlo Park, CA: SRI International.

- Pierce, J. C., Lovrich, N. P., Tsurutani, T., \& Abe, T. (1987). Culture, politics, and mass publics: Traditional and modern supporters of the new environmental paradigm scale in Japan and the United States. The Journal of Politics, 49(1), 54-79. doi: $10.2307 / 2131134$

- Ramsey, C. E., \& Rickson, R. E. (1976). Environmental Knowledge and Attitudes. The J ournal of Environmental Education, 8(1), 10-18. doi: 10.1080/00958964.1976.9941552

- Roth, C. E. (1992). Environmental literacy: Its roots, evolution, and directions in the 1990s. Columbus: ERIC Clearingouse for Science, Mathematics and Environmental Education.

- Sadik, F., \& Sadik, S. (2014). A study on environmental knowledge and attitudes of teacher candidates. Procedia - Social and Behavioral Sciences, 116, 2379-2385. doi: 10.1016/j.sbspro.2014.01.577

- Shiang-Yao, L., Shin-Cheng, Y., Shi-Wu, L., Wei-Ta, F., \& Huei-Min, T. (2015). A National investigation of teachers' environmental literacy as a reference for promoting environmental education in Taiwan. The Journal of Environmental Education, 46(2), 114-132. doi: 10.1080/00958964.2014.999742

- Schovajsová, J. (2010). Současný stav environmentální výchovy na základních školách - vybrané aspekty environmentální gramotnosti dětí mladšího školního věku. Disertační práce. Olomouc: Univerzita Palackého, Pedagogická fakulta, s. 194.

- Svobodová, S. (2013). Vliv environmentální výchovy na úroveň ekogramotnosti žáků základních škol regionu Žatec. Diplomová práce. Praha: ČZU, 108 s.

- Svobodová, S. (2016). Vliv úrovně ekologické gramotnosti učitelů na úroveň ekologické gramotnosti žáků vybraných škol v regionu Žatec. Diplomová práce. Praha: UK, $105 \mathrm{~s}$.

- Svobodová, S. \& Kroufek, R (2016). Environmentální gramotnost žáků 2. stupně v Žatci - výzkumná sonda. Envigogika, Praha, v. 11, n. 2, lis. 2016. ISSN 1802-3061. Dostupné na: <http://www.envigogika.cuni.cz/index.php/Envigogika/article/view/514>. Datum prístupu: 24 led. 2017 doi:http://dx.doi.org/10.14712/18023061.514.

- Swanepoel, C. H., Loubser, C. P., \& Chacko, C. P. C. (2002). Measuring the environmental literacy of teachers. South African J ournal of Education, 22(4), 282-285. 
- Tan, Ç. (2014). An assessment of pre-service teachers' attitudes toward books on environment and, relationship between attitudes and environmental behaviours; environmental thinking. Procedia - Social and Behavioral Sciences, 116, 43574361. doi: 10.1016/j.sbspro.2014.01.946

- Vacínová, M., \& Matějček, T. (2013). Intergenerational differences in personal relationship to nature. Envigogika, 8(2). doi: 10.14712/18023061.384

- van Petegem P., \& Blieck, A. (2006). The environmental worldview of children: a cross-cultural perspective. Environmental Education Research, 12, 5, 625-635.

- Volk, T., Hungerford, H. R., \& Tomera, A. N. (1984). A national survey of curriculum needs as perceived by professional environmental educators. J ournal of Environmental Education, 16(1), 10-19. doi: 10.1080/00958964.1984.9942696

- Wiseman, M., \& Bogner, F. X. (2003). A higher-order model of ecological values and its relationship to personality. Personality and Individual Differences, 34(5), 783-794. doi: A higher-order model of ecological values and its relationship to personality.

- Wiseman, M., Wilson, G., \& Bogner, F. X. (2012). Environmental values and authoritarianism. Psychology Research, 2(1), 25-31.

- Wu, L. (2012). Exploring the New Ecological Paradigm Scale for Gauging Children's Environmental Attitudes in China. The Journal of Environmental Education, $43,2,107-120$. 


\section{Příloha č. 1 Dotazník - 2. stupeň zš}

Milá žákyně, milý žáku

Pečlivým vyplněním tohoto anonymního dotazníku mi můžeš pomoci získat bližší informace o environmentální gramotnosti žáků 2. stupně naší školy.

První část je zaměřena na sociodemografické údaje, druhá na environmentální znalosti a třetí na Tvoje postoje $k$ životnímu prostředí.

Děkuji za Tvé odpovědi.

\section{IDENTIFIKAČNÍ ZNAKY}

Pohlaví:

$$
\square \text { dívka } \square \text { chlapec }
$$

Ročník:
$\square$ 6. třída
7. třída
8. třída
9. třída

Bydlíš ve/na:

$\square$ městě $\square$ vesnici

Trídíte doma odpad pravidelně:

$$
\square \text { ano } \square \text { ne }
$$

Svůj volný čas trávíš nejraději:

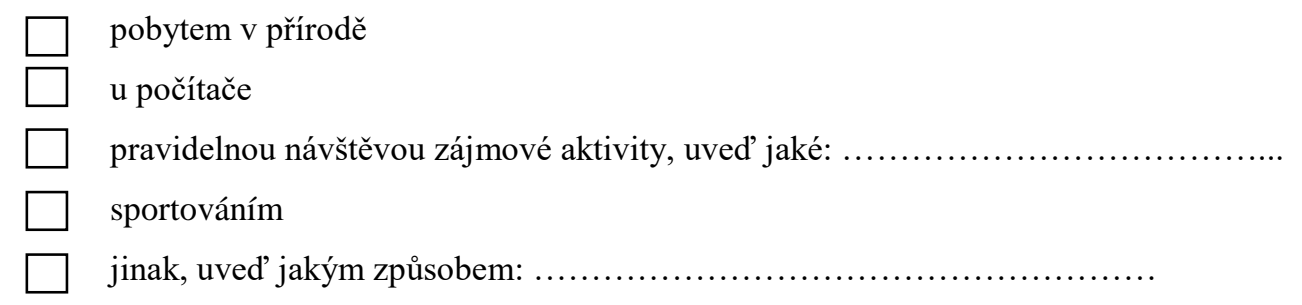

Tvůj nejoblíbenější předmět ve škole: 


\section{TEST EKOLOGICKÝCH ZNALOSTÍ}

U každé otázky zakroužkuj jednu nejlepší odpověd'.

1. opylování sladce vonící květiny s pestře zbarvenými okvětními plátky probíhá s největší pravděpodobností za pomoci:
a) deště
b) větru
c) zahradníka
d) hmyzu

2. Drobný pták sezobne motýla, který saje nektar z květu. Ptáka pak sežere jestřáb. Jedná se o př́klad:
a) vzájemnosti
b) potravního řetězce
c) soupeření
d) přežití silnějšího

3. Který z následujících vztahů je př́kladem vztahu predátora a kořisti?
a) blecha kousne psa
b) červenka sezobne červa
c) housenka sní list
d) srna sní stéblo trávy, na němž sedí kobylka

4. Uhyne liška. Tím vznikne problém pro:
a) blechy sající její krev
b) králíka, který má nedaleko noru
c) lišku ze sousedního teritoria
d) zvíře, které loví na stejném území

5. Termiti se živí pouze dřevem, které ale nejsou schopni trávit. Drobné organismy obývající trávicí soustavu termitů, ale dřevo tráví. Vztah mezi těmito organismy a termity Ize vyjádřit takto:
a) výhodný pro jedny a bez užitku pro druhé
b) výhodný pro jedny a škodlivý pro druhé
c) výhodný pro oba
d) nevýhodný ani pro jedny

6. Kočka a had loví stejnou myš. Jaký je vztah mezi kočkou a hadem?
a) jeden využívá druhého, ale neškodí mu
b) soupeří spolu
c) navzájem si pomáhají 
d) jeden se snaží sežrat druhého

7. Kdyby na Zemi neexistovali rozkladači (rozkladné organismy), co by se stalo?

a) Odumřelé části rostlin a mrtvá zvířata by se nestávaly součástí pưdy.

b) Řada lidských chorob by vymizela.

c) Lidé by měli k dispozici daleko více masa.

d) Téměř nic by se nezměnilo

8. Travnatá pláň se promění v poušt́. Co se nejpravděpodobněji stane se zvířaty, která na pláni žijí?

a) Většina $z$ nich odejde nebo uhyne.

b) Budou se více množit, aby přežila.

c) Ta, co živí trávou, přejdou na jinou potravu.

d) Řada z nich předá potomkům rysy, které jejich mlád’atům pomohou přežít $\vee$ poušti

9. Skupina lidí zavedla ve státním lese program na ochranu vysoké zvěře. V jeho rámci začali lovit vlky. O deset let později už v lese nebyli žádní vlci. Za dalších několik let, kdy vlci už v lese nežili, bylo v lese daleko více vysoké než kdy předtím. Potom náhle téměř všechna vysoká zvěř zmizela. Lidé, kteří chtěli chránit vysokou zvěř, nevěděli, že:

a) Vysoká se dožívá jen několika let.

b) Požáry vyhubí tolik vysoké.

c) Jiná zviřata sežerou vysoké zvěři tolik potravy.

d) Vysoká zvěř spotřebuje veškerou potravu a řada jedinců uhyne

10. Původním zdrojem energie pro všechny živé organismy je:
a) Slunce
b) voda
c) půda
d) rostliny

11. Tělo uhynulého ptáka se rozkládá. Co se stane $\mathrm{s}$ energií uloženou v těle ptáka?

a) Nestane se s ní nic. Jakmile pták uhyne, energie přijde vniveč.

b) Projde organismy, které rozkládají mrtvé tělo.

c) Zničí ji sluneční záření.

d) Pták energií spotřeboval, když byl naživu.

12. Králík sní kukuřici. Energie z kukuřice přejde do králíka. Další den sežere králíka liška. Liška získá z kukuřice jen nepatrné množství energie. Proč? 

a) Králík nedokáže trávit kukuřici.
b) Králík již kukuřici strávil.
c) Kukuřice není př́liš energeticky vydatná.
d) Králík již většinu energie z kukuřice spotřeboval.

13. Většina kyslíku $v$ atmosféře pochází $z$ :
a) hmyzu
b) rostlin
c) půdy
d) Slunce

14. Jakým způsobem mohou lidé získat z tuny rostlin nejvíce energie?

a) Kdyby rostlinným materiálem nakrmili hmyz, ten dali sežrat rybám a poté sami snědli ryby.

b) Lidé by snědli rostliny.

c) Nakrmili by rostlinami dobytek a ten pak snědli.

d) Nakrmili by rostlinami ryby a pak ryby snědli.

15. Poté, co živé organismy uhynou, rozloží se. Výsledkem tohoto procesu je, že živiny:
a) se vrátí zpět do životního prostředí a projdou dalším cyklem.
b) jsou zničeny bakteriemi.
c) se přemění na kyslík a vodní páru.
d) se vypaří vlivem tepla vyprodukovaného při rozkladu.

16. Který z následujících procesů je součástí vodního koloběhu?
a) eroze
b) př́liv oceánů
c) vypařování
d) rozklad

17. Dojde ke znečištění životního prostředí a následně $\mathrm{k}$ úhynu velkého množství hmyzu. Jak se to může projevit na ekosystému?

a) Rostliny nejsou poškozené, takže ekosystém to neovlivní.

b) Dojde k poškození části ekosystému, což ovlivní celý ekosystém.

c) Uhyne pouze hmyz, takže ostatní živočichové zůstanou zdraví.

d) Většina zvířat se živí rostlinami, takže ekosystém to př́liš nezasáhne.

U každého tvrzení vyber a označ křížkem míru Tvého souhlasu. 


\begin{tabular}{|c|c|c|c|c|c|c|}
\hline & & $\begin{array}{l}\frac{E}{\sqrt{n}} \\
\frac{0}{c} \\
\frac{5}{J} \\
i \\
i\end{array}$ & 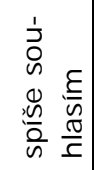 & $\stackrel{\varepsilon}{\stackrel{\varepsilon}{d}}$ & 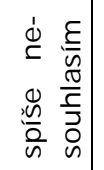 & 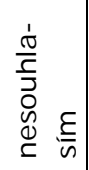 \\
\hline 1. & $\begin{array}{l}\text { Kdybych měl/a nějaké peníze navíc dal/a bych je na } \\
\text { ochranu př́rody. }\end{array}$ & & & & & \\
\hline 2. & $\begin{array}{l}\text { Abych v zimě ušetřil/a energii, zkontroluji, jestli topení v } \\
\text { mém pokoji netopí zbytečně moc. }\end{array}$ & & & & & \\
\hline 3. & Líbilo by se mi sedět na kraji rybníka a pozorovat vážky. & & & & & \\
\hline 4. & $\begin{array}{l}\text { Lidé mají právo měnit své životní prostředí (přírodu) ve } \\
\text { svůj prospěch. }\end{array}$ & & & & & \\
\hline 5. & $\begin{array}{l}\text { Stavět nové silnice je tak důležité, že by se kvůli nim } \\
\text { měly kácet stromy. }\end{array}$ & & & & & \\
\hline 6. & Pomáhal/a bych sehnat peníze na ochranu přírody. & & & & & \\
\hline 7. & Vždy zhasnu světlo, když už nepotřebuji svítit. & & & & & \\
\hline 8. & Rád/a chodím na výlety ven z města, třeba do lesa. & & & & & \\
\hline 9. & $\begin{array}{l}\text { Mám radši udržovaný trávník než louku, kde roste tráva } \\
\text { divoce. }\end{array}$ & & & & & \\
\hline 10. & $\begin{array}{l}\text { Protože komáři žijí v bažinách, měly by se bažiny vy- } \\
\text { sušit a jejich půda využívat pro zemědělství. }\end{array}$ & & & & & \\
\hline 11. & Snažím se říkat ostatním, že příroda je důležitá. & & & & & \\
\hline 12. & $\begin{array}{l}\text { Snažím se šetřit vodou tak, že se sprchuji krátkou dobu } \\
\text { nebo vypínám kohoutek při mytí zubů. }\end{array}$ & & & & & \\
\hline 13. & Mám rád/a klid a ticho př́rody. & & & & & \\
\hline 14. & $\begin{array}{l}\text { Aby měli lidé dost jídla, musí se divoká príroda přeměnit } \\
\text { na pole. }\end{array}$ & & & & & \\
\hline 15. & Lidé mají vládnout přírodě. & & & & & \\
\hline 16. & $\begin{array}{l}\text { Plevel by se měl vyhubit, protože zabírá místo rostli- } \\
\text { nám, které potřebujeme. }\end{array}$ & & & & & \\
\hline
\end{tabular}

